\title{
PATH ANALYSIS: PSYCHOSOSIAL AND ECONOMIC FACTORS AFFECTING DIARRHEA INCIDENCE IN CHILDREN UNDER FIVE IN JAYAPURA, PAPUA
}

\author{
Tersia Marentiva Tungga'), Yulia Lanti Retno Dewi²), Bhisma Murti3) \\ ${ }^{1)}$ Master Program in Public Health, Universitas Sebelas Maret \\ 2)Department of Perinatal, Hospital Dr. Moewardi, Surakarta \\ 3)Department of Public Health, Faculty of Medicine, Universitas Sebelas Maret
}

\begin{abstract}
Background: Diarrhea is a major cause of malnutrition and death in children under five. Studies have shown that there are some factors contributing to the incidence of diarrhea in infants. This study aimed to examine the psychososial and economic factors affecting diarrhea incidence in children under five in Jayapura, Papua.

Subjects and Method: This was an analytic observational study with a crosssectional design. The study was conducted in North Jayapura Subdistrict, Papua in February 2018. A sample of 200 children under five was selected for this study by fixed disease sampling, consisting of 100 children with diarrhea and 100 children without diarrhea. The dependent variable was diarrhea. The independent variables were maternal education, family income, exclusive breastfeeding, nutritional status, personal hygiene, and environmental sanitation. The data were collected by questionnaire. Path analysis was employed for data analysis in Stata 13.

Results: The risk of diarrhea increased with poor personal hygiene $(b=-1.04$; $95 \% \mathrm{CI}=-1.75$ to $-0.33 ; \mathrm{p}=0.004)$, poor environmental sanitation $(\mathrm{b}=-1.90 ; 95 \%$ $\mathrm{CI}=-2,59$ to $-1.21 ; \mathrm{p}<0.001)$, poor nutritional status $(\mathrm{b}=-1.27 ; 95 \% \mathrm{CI}=-2.02$ to $0.52 ; \mathrm{p}=0.001)$. The risk of diarrhea was indirectly affected by exclusive breastfeeding, maternal education, and family income.

Conclusion: The risk of diarrhea increases with poor personal hygiene, poor environmental sanitation, poor nutritional status, and indirectly affected by exclusive breastfeeding, maternal education, and family income.
\end{abstract}

Keywords: psychosocial factor, economic factor, diarrhea, children under five

\section{Correspondence:}

Tersia Marentiva Tungga. Masters Program in Public Health, Universitas Sebelas Maret, Jl. Ir. Sutami No. 36 A, Surakarta 57126, Central Java.

Email: tersiatungga@gmail.com. Mobile: +6285244754188.

Mid-International Conference in Public Health, 